\title{
Nilai-Nilai Religius Dalam Kumpulan Puisi Tadarus Karya KH. Ahmad Mustofa Bisri
}

\author{
Ade Rufaida Awalia ${ }^{a, 1}$, Yumna Rasyid ${ }^{\mathrm{a}, 2}$, dan Zuriyati ${ }^{\mathrm{a}, 3}$ \\ ${ }^{a}$ Universitas Negeri Jakarta, Indonesia

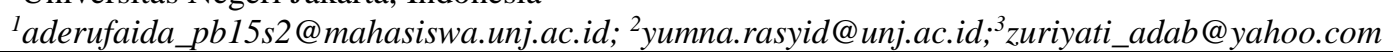 \\ Article info \\ A B S TR A C T \\ Article history: \\ Received: 07-04-2019 \\ Revised : 06-10-2019 \\ Accepted: 06-11-2019 \\ Poetry as a literary work has an aesthetic value in it. However, in \\ practice often the reader does not understand the implicit meaning in \\ $i t$. For example, the aspect of religiosity that is often overlooked in a \\ poem that is trying to be communicated using a semiotic element. This \\ study aims to describe the values of religiosity in the collection of \\ Tadarus poetry (1) through the depiction of icons, (2) through the \\ depiction of indices, and (3) through the depiction of symbols. This \\ study uses a qualitative research design, the method used is \\ descriptive, while the approach used is semiotic. From the analysis of \\ semiotics it was found that Tadarus's poetry often included semiotic \\ elements in his stanzas.
}

Keywords:

Ahmad Mustofa Bisri

poetry

semiotic

Tadarus

religiosity

Puisi sebagai suatu karya sastra memiliki nilai estetik di dalamnya. Akan tetapi, dalam praktiknya sering kali pembaca tidak memahami makna tersirat di dalamnya. Misalnya saja aspek religiusitas yang sering kali diabaikan di dalam suatu puisi yang coba dikomunikasikan menggunakan unsur semiotik. Penelitian ini bertujuan untuk, mendeskripsikan nilai-nilai religiusitas dalam kumpulan puisi Tadarus (1) melalui penggambaran ikon, (2) melalui penggambaran indeks, dan (3) melalui penggambaran simbol. Penelitian ini menggunakan desain penelitian kualitatif, metode yang digunakan deskriptif, sedangkan pendekatan yang digunakan semiotik. Dari analisis semiotika ditemukan bahwa puisi Tadarus banyak menyisipkan unsur semiotika di dalam bait-baitnya.

Copyright $\odot 2019$ Institut Agama Islam Negeri Syekh Nurjati Cirebon.

PENDAHULUAN

All rights reserved.

Era modern, kehidupan manusia kompleks dengan berbagai masalah. Baik masalah antara manusia, antarmasyarakat atau manusia dengan Tuhannya. Sebuah karya sastra merupakan hasil dari imaji, perenungan, pengalaman, pengetahuan, ide, dan gagasannya seorang pengarang. Selain itu, puisi merupakan suatu bentuk kecintaan terhadap bahasa Indonesia (Hudaa, 2018). Karya sastra merupakan hasil dari kreativitas pengarang, yang nanti akan dibaca oleh orang banyak. Oleh karena itu, sebuah karya harus memiliki manfaat yan baik ketika dibaca.

Saat ini keadaan masyarakat, umumnya sudah mulai timbul permasalahan yang sebab musababnya berasal dari kurangnya nilai-nilai keagamaan yang dimiliki. Puisi bisa dijadikan media pembelajaran siswa di sekolah agar lebih 


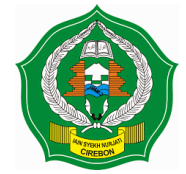

mengenal nilai-nilai keagamaan melalui sebuah karya pengarang yang di dalamnya mengandung nilai-nilai keagamaan. Untuk itu, sebuah karya yang memiliki nilai mendidik sangat dibutuhkan pada era globalisasi. Dengan media puisi, dapat memberikan nilai budi pekerti yang baik, serta memberikan gambaran tentang kekuasaan Tuhan dalam menciptakan alam semesta dan keindahannya (Lathief, 2008).

Puisi merupakan ungkapan jiwa atau sifat yang keluar dari dalam diri. Puisi mempertimbangkan efek keindahan dengan ketentuan-ketentuan tertentu yang terdiri dari irama, sajak dan kata-kata kias yang penuh makna (Ahmad \& Aswinarko, 2013). Puisi adalah hasil ekpresi penyair sebagai penulis puisi untuk memberi pesan kepada pembaca. Puisi itu sendiri mempunyai arti sebagai gambaran diri sendiri atau pribadi penyair yang ada di pikirannya (Siswantoro, 2010). Puisi merupakan ungkapkan perasaan pengarang serta pikiran, yang dituangkan melaluli sebuah karya — disusun dengan penuh konsentrasi-kekuatan bahasanya, sehingga memiliki makna (Hindun, 2014). Dengan demikian puisi adalah luapan perasaan, pengimajinasiaan seseorang dalam menuangkan ide yang asal muasalnya dari hati dan pikiran.

Nilai adalah suatu yang penting dalam hidup manusia, karena memberi arti bahkan manusia rela berkorban demi sebuah nilai (Jalaludin, 2016). Pendapat lain mengatakan bahwa seseorang memiliki kepribadian yang sempurna, ketika memiliki banyak nilai. Terciptanya kesempurnaan, bila seseorang mampu stabil dan menyeimbangi potensi dalam dirinya (Tumanggor et. al, 2010).

Sementara, religiusitas merupakan sebuah nilai hidup manusia, yang dimaknai sebagai rasa kebersamaan yang menyatu pada sesuatu yang tidak dapat terlihat hanya dengan seseorang mengerti agama, tetapi religiusitas itu kegiatan yang dilakukan seseorang secara konsiten dalam hidupannya sehari-hari. Oleh karenanya peran guru sangat penting dalam dunia pendidikan. Guru berperan dalam mempertahankan kesehatan mental bangsa dengan pengetahuannya. Maka dari itu, guru harus memilki keahlian khusus dan berkepribadian yang baik. Tugas mulia guru adalah bisa membimbing, mengajarkan pengetahuan, mendidik baik sikap maupun perilaku.

Melihat hal tersebut, sudah seharusnya guru memiliki kepribadian dan pemahaman yang baik tentang agama. Dengan demikian tugas guru bukan hanya 
mengajarkan peserta didiknya, tetapi juga menanamkan nilai-nilai dasar untuk membangun karakter atau akhlak peserta didik sesuai ajaran agama. Keteladanan seorang guru adalah segala yang dapat diberikan untuk keberhasilan anak didiknya. Marilah tanamkan nilai-nilai yang baik dalam pembelajaran kepada peserta didik, seperti nilai pendidikan, nilai moral, nilai akhlak dan nilai religius. Dalam hal ini nilai religiusitas dapat ditanamkan tidak hanya pada diri sendiri. Namun di sekolah juga dapat ditanamkan sebagai pembelajaran yang dimanfaatkan dengan menggunakan karya sastra.

Puisi merupakan sebuah karya yang dapat dipelajari siswa di sekolah. Dengan puisi siswa bisa mempelajari nilai religiusitas di sekolah. Guru bisa memberikan puisi-puisi yang kaya akan nilai keagamaan, karena siswa tidak hanya membutuhkan nilai moral, nilai pendidikan tetapi membutuhkan nilai religiusitas. Dalam kenyataanya di sekolah nilai religiusitas atau nilai keagamaan seringkali terabaikan. Moral atau perilaku siswa yang sudah tidak sesuai dengan aturan-aturan keagamaan. Seperti siswa tauran, suka melawan perintah guru, melawan orang tua, siswa laki-laki menyukai sejenisnya semua itu karena kurangnya pengetahuan tentang nilai religiusitas atau keagamaan. Puisi-puisi Kh. Ahmad Mustofa Bisri menghadirkan pengalaman religiusitas mengenai hubungan antara manusia dengan manusia dan manusia dengan Sang Pencipta.

Pengarang melalui puisi dapat mengidentifikasi religiusitas yang tertuang di dalamnya. Adapun nilai religuisitas ini meliputi aqidah, syariah, dan akhlak. Pada dasarnya, puisi merupakan bahasa pengarang yang berasal hasil refleksi pemikiran, perasaan. Kebahasaan dalam puisi itu merupakan gaya bahasa yang khas yaitu bahasa yang memuat tanda-tanda.

Penelitian Adri (2011) mendeskripsikan pembacaan puisi dengan kajian heuristik dan hermeneutik, dan dianalisis melalui ikon, simbol indeks yang memiliki nilai ajaran agama Islam. Penelitian Fadli (2015) menggunakan objek puisi dan pendekatan semiotik Riffataere. Penelitian Luisya (2015) menggunakan kajian struktural semiotik Pierce. Mudjiono (2011) melakukan kajian Semiotika pada sebuah film. Heru (2012) menganalisis nilai religius pada perilaku difungsional audit sebuah puisi. Wirawan (2016) melakukan analisis struktural pada antalogi pusi.

Lestari (2017) melakukan kajian stilistika sebuah puisi sebagai materi ajar 
Bahasa Indonesia di SMA. Penelitian ini bertujuan mendeskripsikan diksi, gaya bahasa dan lainnya. Sedangkan Peneliti bertujuan mendeskipsikan simbol, ikon dan indeks. Mayrita (2014) menggali makna yang tersirat dalam bahasa sebuah puisi dengan pendekatan sosiologi sastra. Simarmata (2014) menganalisis puisi dengan pendekatan hermeneutik. Demikian juga dengan Ade (2014) yang menganalisis konsep masyarakat Melayu Jambi terhadap seloko adat dalam berkomunikasi. Heri (2017) melakukan kajian terhadap sebuah sajak dengan pendekatan semiotik Pierce.

Penelitian ini berfokus pada puisi religiusitas yang memiliki nilai keagamaan atau nilai yang mengagungkan ketuhanan. Pemilihan tiga puisi $\mathrm{Kh}$. Ahmad Mustofa Bisri dalam penelitian ini didasarkan dua alasan. KH. Ahmad merupakan seorang penyair yang produktif dengan karya-karyanya. Pemilihan delapan puisi ini berdasarkan pilihan kata atau kosakata keagamaan yang terdapat dalam puisi tersebut baik dari segi judul maupun bait-perbait dan isi puisi yang terddapat nilai-nilai religiusitas. Ketiga puisi tersebut merupakan Pesona, Tadarus, dan Selamat Tahun Baru Kawan .

\section{METODE}

Pendekatan penelitian yang digunakan adalah pendekatan kualitatif, sedangkan metode yang digunakanan adalah metode analisis isi. Penelitian kualitatif menekankan pada aspek deskriptif yaitu memberikan ulasan hasil penelitian dengan menggunakan teks (Hudaa, 2018). Penggunaan pendekatan kualitatif dianggap mampu memberikan penjelasan secara detail dan terperinci. Selain itu, analisis isi yang diterapkan di dalam puisi ini membuat peneliti memiliki waktu untuk melakukan analisis kapan saja dan di mana saja.

\section{HASIL DAN PEMBAHASAN}

Nilai-nilai religiusitas yang terkandung dalam kumpulan puisi Tadarus Karya KH. Ahmad Mustofa Bisri berupa penggambaran aqidah, syariah, akhlak melalui ikon, indeks, dan simbol.

\section{Nilai Religius dalam Penggambaran Aqidah}

Akidah merupakan sebuah keyakinan atau kepercayaan yang harus ada dalam hidu manusia. dengan akidah hidup akan lebih terarah, karena akidah 
merupakan fondasi utama agama Islam. Ulama harus mmberikan pembelajaran yang menyeluruh kepada masyarakat, bahwa akidah sangat penting dalam kehidupan. Hidup tanpa ada pondasi atau bangunan (akidah), maka semua akan roboh atau sia-sia (Marzuki, 2012). Akidah bagaikan cahaya dalam hidup, tanpa akidah maka hidup akan gelap. Jika kegelapan memenuhi hidup manusia, maka dapat dipastikan masuk ke dalam lembah kesesatan (Sayyid, Aqidah Islamiyah, 2010).

\section{Melalui ikon}

(Tidakkah manusia itu tahu saat isi kubur dihamburkan

Saat isi dada ditumpahkan?

Sungguh Tuhan mereka

Terhadap mereka saat itu tahu belaka!)

(Tadarus, bait ke 15, baris ke 55-58, h. 46)

Dari bait tersebut menggambarkan religiusitas dalam penggambaran Aqidah yakni aqidah iman kepada hari kiamat, yaitu "isi kubur dihamburkan". "isi kubur dihamburkan" sebagai representasi yang merujuk kepada interpretasi bahwa Allah mengetahui apa yang akan terjadi ketika isi kubur dibangkitkan dan diperlihatkan segala perbuatan manusia oleh Allah SWT.

Semua tenggelam dalam kekhusyukan-asyik yang ajaib bagai tersihir pesona gaib

Bagai wali-wali Allah dalam keadaan fakta fana ketika mengeja isyaratisyaratNya

(Pesona bait ke 2, baris ke 10-13, h.4)

"Dari bait tersebut menggambarkan religiusitas dalam penggambaran aqidah yakni aqidah iman kepada Allah, yaitu "mengeja isyarat-isyaratNya". "Mengeja isyarat-isyaratNya" sebagai representasi yang merujuk kepada interpretasi berupa seperti sikapnya orang yang beriman, apapun keadaanya ia akan mempelajari isyarat-isyarat keagamaan dengan sebaik-baiknya.

\section{Melalui indeks}

(Itulah hari manusia bagaikan belalang bertebaran

Dan gunung-gunung bagaikan bulu dihambur terbangkan)

Menggigil ruas-ruas tulangku dalam firmanmu

(Tadarus, Bait ke 21-22, Baris Ke 74-76, h.47)

Dari bait tersebut menggambarkan religiusitas dalam penggambaran Aqidah yakni aqidah iman kepada Allah, yaitu "Menggigil ruas-ruas tulangku dalam 


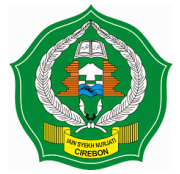

firmanMu”. "Menggigil ruas-ruas tulangku dalam firmanMu” sebagai representasi yang merujuk kepada interpretasi bahwa manusia merasakan firmanfirman Allah yang mendalam hingga membuat tulangnya terasa ikut menggigil.

Kawan sudah tahun baru lagi

Belum juga tibakah saat kita menunduk

Memandang diri sendiri Bercermin firman Tuhan

Sebelum kita dihisabNya

(STBK, bait ke 1, baris ke 1-5, h. 49)

Dari bait tersebut menggambarkan religiusitas dalam penggambaran Aqidah yakni aqidah iman kepada hari kiamat, yaitu "dihisab-Nya". "Dihisab-Nya" sebagai representasi yang merujuk kepada interpretasi bahwa segala amal hidup manusia akan diperhitungkan pada hari pembalasan dan diminta pertanggungjawabannya.

\section{Melalui simbol}

Ya Tuhan, kemana gerangan butir debu ini kan menghambur?

Adakah secercah syukur menempel

Ketika isi dada dimuntahkan

Ketika semua kesayangan dan andalan entah kemana?

Meremang bulu romaku diguncang firmanmu

(Tadarus, Bait ke 17, baris ke 58-63, h. 46)

Dari bait tersebut menggambarkan religiusitas dalam penggambaran aqidah yakni iman kepada Allah, yaitu "Meremang bulu romaku diguncang firmanMu”. “Meremang bulu romaku diguncang firmanMu" sebagai representasi yang merujuk kepada interpretasi bahwa jiwa dan perasaan manusia akan terguncang oleh firman Allah. Segala yang ada di bumi atau di dunia ini akan musnah, baik dari hal-hal yang disayangkan atau benda-benda mati yang dimiliki.

Iman kita kepada Allah dan yang ghaib

Rasanya lebih tipis dari yang kertas ribuan

Lebih pipih dari kain rok perempuan

Betapapun tersiksa kita khusu di depan massa

(STBK, bait ke 3, baris ke 16-19, h. 49)

Dari bait tersebut menggambarkan religiusitas dalam penggambaran Aqidah yakni aqidah iman kepada Allah yaitu "kain rok perempuan". "kain rok perempuan" sebagai representasi yang merujuk kepada interpretasi bahwa iman seseorang dalam hidup kadang tak selamanya mulus tetapi ada pasang surutnya. Dan imannya manusia sangatlah tipis atau sedikit, seperti kain rok perempuan. 


\section{Nilai Religius dalam penggambaran Syariah}

Syariah adalah semua peraturan agama yang ditetapkan Allah untuk kaum muslim baik yang ditetapkan dengan Alquran maupun dengan sunah Rasul (Marzuki, 2013) Syariah adalah segala sesuatu yang diperintahkan oleh agama untuk dilaksanakan segara perintah dengan sebaik-baiknya, yang sesuai dengan aturan dan hukum sebagai perwujudan dari akidah.

\section{Melalui ikon}

Zakat kita jauh lebih berat terasa

Dibanding tukang becak melepas penghasilannya

Untuk kopun undian yang sia-sia

(STBK, bait ke 6, baris ke 37-39, h. 50)

Dari bait tersebut menggambarkan religiusitas dalam penggambaran syariah yakni syariah mengeluarkan zakat yaitu "zakat kita jauh lebih berat terasa". "Zakat kita jauh lebih berat terasa" sebagai representasi yang merujuk kepada interpretasi bahwa manusia sangat berat untuk mengeluarkan zakat yang memang wajib untuk dikeluarkan, karena manusia sangatlah sayang kepada hartanya.

Haji kita tak ubahnya tamasya menghibur diri

Mencari pengalaman spiritual dan material

Membuang uang kecil dan dosa besar

Lalu pulang membawa label suci

Asli made in Saudi : Haji

(STBK, bait ke 8, baris ke 45-49, h. 50)

Dari bait tersebut menggambarkan religiusitas dalam penggambaran syariah yakni syariah mengeluarkan zakat yaitu "Haji kita tak ubahnya tamasya menghibur diri". "Haji kita tak ubahnya tamasya menghibur diri" sebagai representasi yang merujuk kepada interpretasi tujuan dilakukannya ibadah haji, bukan untuk beribadah atau mendekatkan diri kepada sang khalik, tetapi pergi Haji hanya sekedar hiburan atau tamsya.

\section{Melalui indeks}

Sholat kita rasanya lebih buruk daripada senam ibu-ibu

Lebih cepat daripada menghirup kopi panas

Dan lebih ramai daripada lamunan seribu anak muda

(STBK, bait ke 6, baris ke 26-28, h. 50)

Dari bait tersebut menggambarkan religiusitas dalam penggambaran syariah yakni syariah mendirikan salat yaitu "sholat kita rasanya lebih buruk daripada 
senam ibu-ibu". "sholat kita rasanya lebih buruk daripada senam ibu-ibu" sebagai representasi yang merujuk kepada interpretasi bahwa salatnya manusia masih berantakan atau masih bolong-bolong seperti senam ibu-ibu yang berantakan dan sangat tidak rapih. Ketaqwaan dan keimanaan manusia belum seutuhnya untuk beribadah kepada Allah Swt.

Puasa kita rasanya sekedar mengubah jadwal

Makan-minum saat istirahat

Tanpa menggeser acara buat syahwat

(STBK, bait ke 6, baris ke 32-34, h. 50)

Dari bait tersebut menggambarkan religiusitas dalam penggambaran syariah yakni syariah melaksanakan puasa bulan ramadhan yaitu "Puasa kita rasanya sekedar mengubah jadwal Makan-minum saat istirahat". Puasa kita rasanya sekedar mengubah jadwal Makan-minum saat istirahat" sebagai representasi yang merujuk kepada interpretasi bahwa manusia masih belum sadar akan makna puasa itu sendiri. Puasa hanya sekedar menahan lapar, tetapi tidak bisa mengontrol perilaku dan hawa nafsu.

\section{Melalui simbol}

Syahadat kita rasanya seperti perut bedug

Atau pernyataan setia pegawai rendahan saja

Kosong tak berdaya

(STBK, bait ke 4, baris ke 23-25, h. 49)

Dari bait tersebut menggambarkan religiusitas dalam penggambaran syariah yakni syariah mengucap syahadat yaitu "Syahadat kita rasanya seperti perut bedug". "Syahadat kita rasanya seperti perut bedug" sebagai representasi yang merujuk kepada interpretasi seperti kulit bedug yang dalamnya kosong namun bunyinya sangat kencang jika dipukul.

\section{Zakat kita jauh lebih berat terasa}

Dibanding tukang becak melepas penghasilannya

Untuk kopun undian yang sia-sia

(STBK, bait ke 7, baris ke 35-39, h. 50)

Dari bait tersebut menggambarkan religiusitas dalam penggambaran syariah yakni syariah dalam membayar zakat yaitu 'Zakat kita jauh lebih berat terasa'. 'Zakat kita jauh lebih berat terasa' sebagai represetamen yang merujuk dalam membayar zakat, manusia sangat susah. Berat rasanya untuk membayar kewajiban saja. Apalagi untuk memberi hartanya di luar kewajiban. 


\section{Nilai Religius dalam penggambaran akhlak}

Akhlak adalah sifat yang ada dalam diri serta jiwa manusia, yang mampu mendorong seseorang dalam melakukan sesuatu tanpa harus ada pertimbangan dan pemikiran darinya (Abudin, 2001). Akhlah seseorang dapat terlihat ketika melakukan perbuatan baik yang dimovasi dari ajaran agama yang diketahuinya, seperti berperilaku baik dengan sesama. Dalam hal ini seperti, tolong menolong, jujur, pemaaf, menjaga kebersihan lingkungan, berlaku adil, tidak mabukmabukan, menghidari judi, menghindari minum-minuman memabukan, amanah, mematuhi aturan-aturan yang berlaku dalam agama Islam dan dan sebagainya.

\section{Melalui ikon}

Tetanggaku, hari-hari bersimpuh terpaku menghadap kesatu kiblat menyimak sepenuh jiwa raga entah apa

(Pesona bait ke 1, baris ke 3-4, h. 4)

Dari bait tersebut menggambarkan religiusitas dalam penggambaran akhlak yakni akhlak kepada Allah, yaitu "menghadap kesatu kiblat”. "Menghadap kesatu kiblat" sebagai representasi yang merujuk kepada interpretasi berupa kegiatan beribadah yang tujuannya hanya kepada Allah dengan menghadap ke arah kiblat, yaitu arah yang dijadikan patokan umat Islam dalam beribadah.

(ketika itu bumi mengisahkan kisah-kisahnya

Karena Tuhamu mengilhaminya

Ketika itu manusia tumpah terpisah-pisah

Tuk diperlihatkan perbuatan-perbuatan mereka

(Tadarus, bait ke 5, baris ke 14-17, h.44)

Dari bait tersebut menggambarkan religiusitas dalam penggambaran akhlak yakni akhlak kepada Allah, yaitu "Tuk diperlihatkan perbuatan-perbuatan mereka”. "Tuk diperlihatkan perbuatan-perbuatan mereka” sebagai representasi yang merujuk kepada interpretasi berupa tanda yang menunjukan bahwa pada hari akhir segala perbuatan manusia di dunia akan diperlihatkan oleh-Nya.

\section{Melalui Indeks}

... dan yang memanfaatkannya ada yang demi ilmu dan kemajuan ada yang demi informasi dan hiburan ada yang demi kepuasan dan kekayaan ada pula yang menggunakannya ikut-ikutan atau asal menggunakan)

(Pesona, bait ke 6, baris ke 37-40, h. 5)

Dari bait tersebut menggambarkan religiusitas dalam penggambaran akhlak yakni akhlak kepada lingkungan hidup, yaitu "dan yang memanfaatkannya”. "dan 
yang memanfaatkannya" sebagai representasi yang merujuk kepada interpretasi berupa seseorang yang ada di dalam lingkungan sekitar, mereka memiliki masingmasing tujuan yang berbeda-beda sehingga terciptalah pemanfaatan yang berbeda pula. Sehingga bagi yang tidak bisa memanfaatkannya, maka benda tersebut jusru akan membahayakan hidupnya sendiri.
(Maka siapa yang berbuat sezarrah kebaikan pun akan melihatnya
Dan siapa yang berbuat sezarrah kejahatan
pun akan melihatnya)
(Tadarus, Bait ke 4-6, baris ke 14-23, h. 44)

Dari bait tersebut menggambarkan religiusitas dalam penggambaran Aqidah yakni aqidah keimanan kepada Allah, yaitu "maka siapa yang berbuat sezarrah kebaikan pun akan melihatnya". "Maka siapa yang berbuat sezarrah kebaikan pun akan melihatnya" sebagai representasi yang merujuk kepada interpretasi bahwa barang siapa yang melakukan sedikit kebaikan akan terlihat kebaikannya, dan begitu juga jika berbuat sedikit kejahatan pun maka akan terlihat.

\section{Melalui simbol}

Meja makan apalagi meja belaja hari-hari terlantar

Telpon yang berdering-dering, pintu yang diketuk-ketuk

Tamu, bahkan pengeras suara yang melengking-lengkingan adzan tak terdengar. (Pesona bait ke 1, baris ke 5-8, h. 4)

Dari bait tersebut menggambarkan religiusitas dalam penggambaran akhlak yakni akhlak kepada Allah, yaitu "adzan tak terdengar". "Adzan tak terdengar" sebagai representasi yang merujuk kepada interpretasi berupa tanda yang menunjukan panggilan waktu shalat kepada umat muslim.

(sungguh manusia itu kepada Tuhannya

Sangat tidak tahu terima kasih

Sungguh manusia itu sendiri tentang itu menjadi saksi

Dan sungguh manusia itu sayangnya kepada harta luas biasa)

(Tadarus bait ke 13, baris ke 48-50, h. 45)

Dari bait tersebut menggambarkan religiusitas dalam penggambaran Akhlak yakni akhlak terhadap Allah, yaitu "Dan sungguh manusia itu sayangnya kepada harta luas biasa". "Dan sungguh manusia itu sayangnya kepada harta luas biasa" sebagai representasi yang merujuk kepada interpretasi bahwa manusia hidup di dunia haus akan harta, jika diberikan kekayaan atau rizki yang lebih 
manusia lupa untuk beramal. Harta merupakan simbol dari kejayaan atau kemakmuran manusia.

\section{SIMPULAN}

Puisi Tadarus adalah sebuah puisi yang isi di dalamnya terdapat tentang kehidupan. Beberapa nilai religiusitas yang terdapat di dalamnya yaitu tentang pembelajaran agama Islam sebagai agama yang diridai Allah. Pemberitahuan akan datangnya hari kiamat dan keadaan dunia saat kiamat tiba, tentang intropeksi manusia akan segala kekurang dan dosa yang telah diperbuat dan sebagainya. Dalam puisi ini juga mengandung nilai religiusitas berupa akidah, syariah dan akhlak dan nilai kebahasaan berupa ikon, indeks, dan simbol.

\section{DAFTAR PUSTAKA}

Adri. (2011). Analisis Puisi Pada Akhirnya Karya Husni Djamaludin Pendekatan Semiotika. Metasastra, 4, 105-115.

Bahtiar, A. \& Aswinarko. (2013). Kajian Puisi: Teori dan Praktik. Jakarta: Unindra Pres.

Fadli, Z. A. (2015). Kajian Semiotik: Interpretasi Puisi Kurofuno Karya Kinoshita Mokutaro. Izumi 4, 69-75.

Hindun. (2014). Pembelajaran Apresiasi Bahasa dan Kreasi Karya Sastra. Jakarta: Mazhab Ciputat.

Hudaa, S. (2018). Efektivitas Pembelajaran Bahasa Indonesia Menggunakan Pendekatan Student Active Learning di Jurusan Manajemen Fakultas Ekonomi dan Bisnis UIN Syarif Hidayatullah. BAHASTRA, 38(1), 69—74.

Isnaini, H. (2017). Analisis Semiotika Sajak "Tuan" Karya Sapardi Djoko Damono." Deiksis 4, 1-7.

Jabrohim. (2012). Teori Penelitian Sastra. Yogyakarta: Pustaka Pelajar.

Jalaludin. (2016). Psikologi Agama. Jakarta: PT. Raja Grafindo Persada.

Kamagi, L. (2015). Nilai-Nilai Humaniora dalam Antalogi Puisi "Blues untuk Bonnie" Karya WS Rendra. Bahtera 1: 26 - 38.

Langko, I. B. (2014). Penerapan Pendekatan Semiotik untuk Meningkatkan Kemampuan Membaca Puisi Siswa Kelas 7 SMPN 4 Tanantovea. Jurnal Kreatif Tadulako Online 2: 369-387. 
Lathief, S I. (2008). Sastra : Eksistensialisme : Mistisme Religius. Lamongan: Pustaka Ilalang.

Lestari, W. Y. (2017). Kajian Stilistika Kumpulan Puisi Asal Muasal PelukanKarya Candra Malik Sebagai Materi Ajar Bahasa Indonesia di SMA. Basastra 5: 207-219.

Marzuki. (2012). Pembinaan Karakter Mahasiswa Melalui Pendidikan Agama Islam. Yogyakarta: Ombak.

Marzuki. (2013). Pengantar Studi Hukum Islam : Prinsip Dasar Memahami Berbagai Konsep dan Permasalahan Hukum di Indonesia. Yogyakarta: Ombak.

Mayrita, H. (2014). "Makna yan Tersirat dalam Bahasa Puisi Jangan Tanggung Jangan Kepalang Karya Sutan Ali Syahbana." Jurnal Ilmiah Bina Bahasa (17-26) 7.

Mudjiono, Y. (2011). "Kajian Semiotika dalam Film." Jurnal Ilmu Komunikasi (1) $1: 125-138$.

Muhamad, A K. (2005). Ilmu Sosial dan Budaya Dasar. Bandung: PT. Citra Aditya Bakti.

Nata, A. (2001). Akhlak Tasawuf. Jakarta: PT. Raja Grafindo Persada.

Nuryatin, F \& Agus. (2017). Religiusitas dan Syair-Syair Tegalan karya Imam Chumedi." Seloka 1: 100-110.

PIBSI Organization, Simposium Nasional, and Universitas Ahmad Dahlan. 2002. Bahasa dan Sastra Indonesia Menuju Peran Transformasi Sosial Budaya Abad XXI. Gama Media.

Rahima, A. (2014). Nilai-Nilai Religius Seloka Pada Masyarakat Melayu Jambi (Telaah Struktural Semiotik). Jurnal Ilmiah Universitas Batanghari Jambi 14: $1-8$.

Sabiq, S. (2010). Aqidah Islamiyah. Jakarta: Robbani Press.

Simarmata, M. Y. (2014). Kajian Puisi Kontemporer Parsiak Na Bagi KaryaThomson HS dengan Pendekatan Hermeneutik. Jurnal Pendidikan Bahasa 3: 146-160.

Siswantoro. (2010). Metode Penelitian Sastra: Analisis Struktur Puisi. Yogyakarta: Pustaka Pelajar.

Sulistyo, H. (2014). Relevansi Nilai Religius dalam Mencegah Fungsi Difungsional Audit. Jurnal Ekonomi Managemen dan Akuntansi 36: 1-12. 


\section{Indonesian Language Education and Literature}

e-ISSN: 2502-2261

http://www.syekhnurjati.ac.id/jurnal/index.php/jeill/

Vol. 5, No. 1 Desember 2019, 86 - 98

Tumanggor, R. et. al. (2010). Ilmu Sosial dan Budaya Dasar. Jakarta: Prenada Media Group.

Wirawan, G. (2016). Analisis Struktural Antalogi Puisi Hujan Lolos di Sela Jari Karya Yudhiswara. Jurnal Pendidikan Bahasa dan Sastra Indonesia 1: 3944. 